\title{
ANALISA KEBUTUHAN SISTEM APLIKASI BURSA KERJA KHUSUS DI SMK NEGERI 2 KARAWANG
}

\author{
Lila Setiyani $^{1}$, Novia Larasati Setyo Ningrum²
}

${ }^{1}$ Sistem Informasi, STMIK Rosma, Karawang, Indonesia

${ }^{2}$ Sistem Informasi, STMIK Rosma, Karawang, Indonesia

${ }^{1}$ lila.setiyani@dosen.rosma.ac.id, 22novia.larasati@mhs.rosma.ac.id

\begin{abstract}
ABSTRAK
Bursa Kerja Khusus (BKK) adalah sebuah lembaga yang di dirikan disekolah untuk membantu para siswa-siswa untuk mencari pekerjaan dengan bantuan pihak sekolah. Lembaga ini di dirikan secara resmi dan sudah mendapatkan izin dari Dinas Tenaga Kerja dan Transmigrasi. BKK berperan sebagai lembaga memberi informasi lowongan kerja dan penyalur tenaga kerja. BKK SMK Negeri 2 Karawang juga terbuka untuk kalangan umum tak hanya untuk siswa-siswa SMK Negeri 2 Karawang saja. Pengelolaan sistem informasi dan data yang digunakan di BKK SMKN 2 Karawang saat ini masih menggunakan cara manual, sehingga dalam pembuatan laporan perkembangan data pelamar serta data perusahaan menjadi kurang efektif dan efisien. Penelitian ini bertujuan untuk menganalisa kebutuhan sistem informasi dalam, termasuk identifikasi masalah dengan menggunakan metode analisa PIECES, analisa sebab akibat serta akar masalah dengan solusinya menggunakan analisa Fishbone. Dalam menganalisa kebutuhan sistem akan digambarkan dengan alur kerja sistem diagram usecase. Hasil dari observasi serta wawancara yang dilaakukan ini, ditemukan beberapa masalah dan beberapa faktor penyebab yang mengakibatkan manajeme sulit dalam pembuatan laporan. Dari masalah-masalah yang telah diidentifikasi akar masalahnya, berdasarkan proses input dan output serta solusinya yang menjadi landasan dalam menghasilkan informasi kebutuhan-kebutuhan fungsional yang diperlukan dalam membangun sistem informasi dalam Aplikasi BKK membutuhkan sistem informasi manajemen untuk menyelesaikan permasalahan pelaporan, pencarian dan perkembangan data pelamar serta data perusahaan.
\end{abstract}

Kata Kunci- BKK, Analisa PIECES, Analisa Fishbone, Sistem.

\begin{abstract}
The Special Occupation Exchange (BKK) is an institution established in schools to help students find work with the help of the school. This institution was established officially and has received permission from the Department of Manpower and Transmigration. The BKK acts as an institution providing information on job vacancies and recruitment of workers. BKK SMK Negeri 2 Karawang is also open to the general public not only for students of SMK Negeri 2 Karawang. Management of information and data systems used in BKK SMKN 2 Karawang is still using manual methods, so that in making reports on the applicant's data development and company data becomes less effective and efficient. This study aims to analyze the needs of information systems in, including the identification of problems using the PIECES analysis method, cause and effect analysis and the root of the problem with the solution using Fishbone analysis. In analyzing the system requirements will be illustrated by the usecase diagram workflow system. The results of the observations and interviews carried out, found several problems and several causal factors that make management difficult in making reports. From the problems that have been identified the root of the problem, based on the input and output process and the solution that is the basis for producing information on functional requirements needed in building information systems in the BKK Application requires management information systems to solve the problems of reporting, searching and developing applicant data and company data.
\end{abstract}

Keywords-BKK, PIECES Analysis, Fishbone Analysis, Systems. 
Jurnal Ilmiah Ilmu Komputer Vol. 6, No. 2, September 2020

Fakultas Ilmu Komputer

Universitas AL Asyariah Mandar

\section{PENDAHULUAN}

Bursa Kerja Khusus (BKK) adalah sebuah lembaga yang di dirikan disekolah untuk membantu para siswa-siswa untuk mencari pekerjaan dengan bantuan pihak sekolah. Lembaga ini di dirikan secara resmi dan sudah mendapatkan izin dari Dinas Tenaga Kerja dan Transmigrasi. BKK berperan sebagai lembaga memberi informasi lowongan kerja dan penyalur tenaga kerja. BKK SMK Negeri 2 Karawang juga terbuka untuk kalangan umum tak hanya untuk siswa-siswa SMK Negeri 2 Karawang saja.

Saat ini pengelolaan informasi mengenai lowongan kerja yang digunakan di BKK masih menggunakan sistem manual, dengan harus datang secara langsung ke BKK untuk mengetahui informasi mengenai lowongan kerja yang tersedia atau tidak. Dan untuk melakukan registrasi calon pelamar harus menjadi member terlebih dahulu kemudian mengisi form untuk mengikuti tes lowongan yang tersedia kemudian pihak BKK akan menyalinnya terlebih dahulu kedalam buku besar yang berisi banyak data pelamar untuk mengikuti tes lowongan kerja. Sedangkan saat pendaftaran untuk mengikuti tes terkadang pihak BKK belum mengetahui jadwal pasti pelaksaan tes sehingga pelamar harus datang berkali-kali untuk melakukan rangkain pendaftaran hingga mengikuti tes lowongan kerja. Sedangkan pihak perusahaan harus menghubungi kepala BKK terlebih dahulu jika ingin memberikan informasi lowongan yang tersedia diperusahaannya. Atau bahkan harus datang langsung ke BKK jika perusahaan tersebut belum pernah bekerjasama dengan BKK SMK Negeri 2 Karawang. Dengan sistem yang masih manual membuat pengelolaan informasi tidak efektif dan efisien khususnya dalam hal pembuatan laporan data pelamar dan laporan nama perusahaan yang telah memberikan informasi lowongan. Oleh karena itu dibutuhkan suatu aplikasi yang mampu memberikan kemudahan informasi dibutuhkan.

Dari uraian latar belakang masalah tersebut maka dapat dirumuskan masalah yaitu bagaimana menentukan kebutuhan fungsional yang dibutuhkan untuk membangun sistem informasi dalam Aplikasi BKK SMK Negeri 2 Karawang dengan menggunakan metode analisis pieces dan fishbone.

Dalam penelitian ini terdapat beberapa batasan variabel penelitian yaitu menggunakan analisa pieces untuk mengidentifikasi masalah, menggunakan metode analisa fischbone untuk menganalisa sebab akibat serta menetukan akar masalah beserta solusinya, dan mendefinisikan kebutuhan fungsional sistem yang dibutuhkan.

Tujuan dari penelitian ini yaitu untuk menganalisa kebutuhan fungsional yang dibutuhkan untuk membuat sistem aplikasi BKK SMK NEGERI 2 KARAWANG.

\section{TINJAUAN PUSTAKA}

\subsection{Definisi Bursa Kerja Khusus (BKK)}

Bursa Kerja Khusus (BKK) adalah sebuah lembaga yang dibentuk di Sekolah Menengah Kejuruan Negeri dan Swasta, sebagai unit pelaksana yang memberikan pelayanan dan informasi lowongan kerja, pelaksana pemasaran,
(P) ISSN 2442-451X

(O) ISSN 2503-3832

penyaluran dan penempatan tenaga kerja, merupakan mitra Dinas Tenaga Kerja dan Transmigrasi [1].

Menurut PER.07/MEN/IV/2008 bursa kerja khusus yaitu lembaga pelayanan penempatan tenaga kerja di satuan pendidikan menengah dan satuan pendidikan tinggi. Bursa Kerja Khusus merupakan jembatan antara SMK dengan dunia industri [2].

Adapun tujuan dari BKK (Bursa Kerja Khusus) adalah sebagai berikut [3]:

a. Sebagai wadah dalam mempertemukan tamatan dengan pencari kerja.

b. Memberikan layanan kepada tamatan sesuai dengan tugas dan fungsi masing-masing seksi yang ada dalam BKK.

c. Sebagai wadah dalam pelatihan tamatan yang sesuai dengan permintaan pencari kerja

d. Sebagai wadah untuk menanamkan jiwa wirausaha bagi tamatan melalui pelatihan.

\subsection{Definisi Sistem}

Sistem adalah suatu jaringan kerja dari prosedurprosedur yang saling berhubungan, berkumpul bersamasama untuk melakukan kegiatan atau menyelesaikan suatu sasaran tertentu [4].

Secara sederhana system dapat diartikan sebagi suatu kesatuan atau kumpulan dari unsur maupun variabel yang saling terorganisasai, berinteraksi dan bergantung satu sama lainnya. Sistem sebagai sekelompok elemen-elemen yang berinteraksi dengan maksut yang sama untuk mencapai suatu tujuan. Sumber daya mengalir dari elemen output dan untuk menjamin prosesnya berjalan dengan baik maka dihubungkan dengan mekanisme control [5].

Hanif Al Fatta (2007) Sistem didefinisikan sekumpulan dari objek-objek yang saling berelasi dan berintegrasi atau bekerja sama serta hubungan antar objek bisa dilihat sebagai satu kesatuan yang dirancang untuk mencapai satu tujuan. Dengan demikian secara sederhana sistem dapat diartikan sebagai suatu kumpulan atau himpunan dari unsur atau variabel-variabel yang saling terorganisasi, saling berintegrasi dan saling bergantung sama lain [6]. Sistem terdiri dari unsur-unsur seperti masukkan (input), pengolahan (processing), serta keluaran (output) [6].

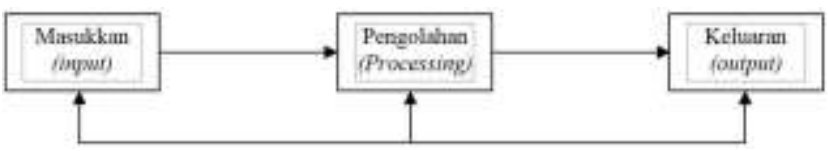

Gambar 1 Unsur-unsur Sistem

\subsection{Analisis PIECES}

Analisis PIECES (Performance, Information, Economy, Control, Eficiency, dan Service) merupakan teknik untuk mengidentifikasi dan memecahkan permasalahan yang terjadi pada sistem informasi. Dari analisis ini akan menghasilkan identifikasi masalah utama 
Jurnal Ilmiah Ilmu Komputer Vol. 6, No. 2, September 2020

Fakultas Ilmu Komputer

Universitas AL Asyariah Mandar

dari suatu sistem serta memberikan solusi dari permasalahan tersebut [7].

Untuk lebih jelasnya lagi mengenai PIECES, di bawah ini akan dijelaskan mengenai pengertian dari masingmasing komponen PIECES [8].

a. Analisis Kinerja Sistem (Performance)

Kinerja adalah suatu kemampuan sistem dalam menyelesaikan tugas dengan cepat sehingga sasaran dapat segera tercapai. Kinerja diukur dengan jumlah produksi (throughput) dan waktu yang digunakan untuk menyesuaikan perpindahan pekerjaan (response time).

b. Analisa Informasi (Information)

Informasi merupakan hal penting karena dengan informasi tersebut pihak manajemen (marketing) dan user dapat melakukan langkah selanjutnya. Apabila kemampuan sistem informasi baik, maka user akan mendapatkan informasi yang akurat, tepat waktu dan relevan sesuai dengan yang diharapkan.

c. Analisis Ekonomi (Economy)

Pemanfaatan biaya yang digunakan dari pemanfaatan informasi. Peningkatan terhadap kebutuhan ekonomis mempengaruhi pengendalian biaya dan peningkatan manfaat. Saat ini banyak perusahaan dan manajemen mulai menerapkan paperless system (meminimalkan penggunaan kertas) dalam rangka penghematan. Oleh karena itu dilihat dari penggunaan bahan kertas yang berlebihan dan biaya iklan di media cetak untuk media publikasi, sistem ini dinilai kurang ekonomis.

d. Analisis Pengendalian (Control)

Analisis ini digunakan untuk membandingkan sistem yang dianalisa berdasarkan pada segi ketepatan waktu, kemudahan akses, dan ketelitian data yang diproses.

e. Analisis Efisiensi (Efficiency)

Efisiensi berhubungan dengan bagaimana sumber tersebut dapat digunakan secara optimal. Operasi pada suatu perusahaan dikatakan efisien atau tidak biasanya didasarkan pada tugas dan tanggung jawab dalam melaksanakan kegiatan.

f. Analisis Pelayanan (Service)

Peningkatan pelayanan memperlihatkan kategori yang beragam. Proyek yang dipilih merupakan peningkatan pelayanan yang lebih baik bagi manajemen (marketing), user dan bagian lain yang merupakan simbol kualitas dari suatu sistem informasi.

\subsection{Fishbone Diagram}

Fishbone Diagram (diagram tulang ikan) dalam alat yang digunakan untuk mengidentifikasi dan mengorganisir penyebab yang mungkin timbul dari suatu masalah. Sering juga disebut Cause-and-Effect Diagram atau Ishikawa Diagram. Ini diperkenalkan oleh Dr. Kaoru Ishikawa, seorang ahli pengendalian kualitas dari Jepang sebagai satu dari tujuh alat kualitas dasar (7 basic quality tools). Fishbone Diagram digunakan ketika kita ingin mengidentifikasi kemungkinan penyebab masalah dan terutama ketika sebuah team cenderung jatuh berfikir pada rutinitas [9].

Suatu tindakan dan langkah improvement akan lebih mudah dilakukan jika masalah dan akar penyebab masalahsudah ditemukan. Manfaat fishbone diagram ini sebagai alat bantu untuk menemukan akar penyebab masalah secara user friendly, tools yang user friendly disukai orang-orang dan dapat digunakan dengan mudah. Fishbone diagram akan mengidentifikasi berbagai sebab potensial dari satu efek atau masalah, dan menganalisis masalah tersebut melalui sesi brainstorming. Masalah akan dipecah menjadi sejumlah kategori yang berkaitan, mencakup manusia, material, mesin, prosedur, kebijakan, dan sebagainya. Setiap kategori mempunyai sebab-sebab yang perlu diuraikan melalui sesi brainstorming [10].

Fishbone Diagram berfungsi untuk mengidentifikasi dan mengorganisasi penyebab-penyebab yang mungkin timbul dari suatu efek spesifik dan kemudian memisahkan akar penyebabnya. Fishbone Diagram sendiri banyak digunakan untuk membantu mengidentifikasi akar penyebab dari suatu masalah dan membantu menemukan ide-ide untuk solusi suatu masalah [11].

Selain definisi mengenai fishbone diatas, analisa fishbone juga berarti [12]:

a. Metode sederhana yang dapat dipergunakan untuk menelusuri penyebab suatu permasalahan yang terjadi.

b. Dalam prosesnya melibatkan semua orang.

c. Dasarnya adalah prinsip bahwa pemikiran yang bersumber dari orang banyak lebih baik dari 1 orang.

d. Dinamakan diagram tulang ikan karena bentuk daridiagram ini seperti tulang ikan, dengan permasalahan sebagai kepalanya, dan penyebabpenyebab yang ada sebagai duri-durinya.

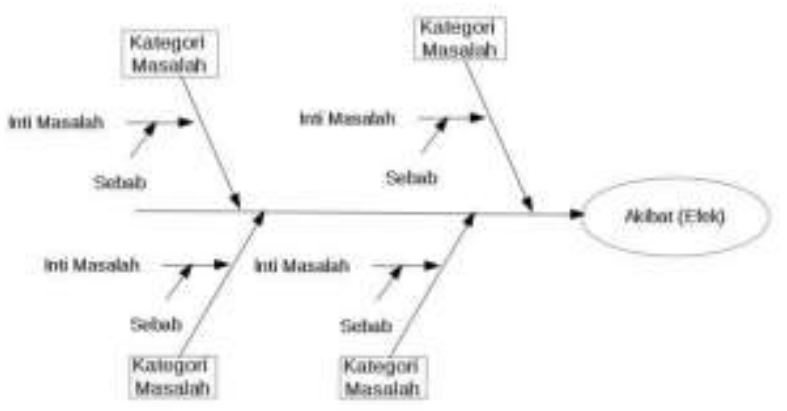

Gambar 2 Contoh Fishbone Diagram

\subsection{Rekayasa Kebutuhan}

Rekayasa kebutuhan fokus menentukan dimensi persoalan atau domain permasalahan yang akan diselesaikan dengan sistem perangkat lunak [13]. Rekayasa kebutuhan perangkat lunak merupakan hal yang penting dalam proses rekayasa perangkat lunak. Salah satu faktor utama kegagalan dalam rekayasa perangkat lunak adalah pada tahap rekayasa kebutuhan tidak dilakukan dengan baik dan benar [14]. 
Jurnal Ilmiah Ilmu Komputer Vol. 6, No. 2, September 2020

Fakultas Ilmu Komputer

Universitas AL Asyariah Mandar

Rekayasa kebutuhan dalam pembuatan perangkat lunak memerlukan beberapa tahap. Tahap pertama yang dilakukan adalah merekayasa kebutuhan. Analisa kebutuhan merupakan kunci utama untuk mendapatkan informasi tentang perangkat lunak yang di butuhkan oleh pengguna atau client [15].

Analisa kebutuhan merupakan bagian dari rekayasa perangkat lunak yang menitik beratkan pada tujuan, fitur atau fungsi kegunaan dan batasan yang ada pada sistem perangkat lunak. Dalam pandangan proses rekayasa perangkat lunak, rekayasa kebutuhan adalah tindakan utama dalam melakukan rekayasa perangkat lunak yang berawal dari kegiatan-kegiatan komunikasi dan berlanjut pada kegiatan permodelan. Rekayasa kebutuhan juga adalah jembatan dari tahap analisis ke tahap perancangan dan konstruksi [16].

Rekayasa Kebutuhan (Requirement Engineering) adalah bagian dari rekayasa perangkat lunak yang berkaitan dengan penemuan (discovering), pengembangan (developing), pelacakan (tracing), penganalisaan (analyzing), pengkualifikasian (qualifying), pengkomunikasian (comunicating), dan pengelolaan (managing) kebutuhan yang mendefinisikan sistem pada tingkat abstraksi [17].

\subsection{Diagram Use Case}

Use Case Diagram adalah diagram yang berfungsi untuk menggambarkan hubungan antara sistem dengan aktor. Elemen-elemen yang digunakan dalam use case diagram adalah sebagai berikut [18]:

a. Sistem merupakan batasan-batasan proses yang telah dideskripsikan pada sebuah sistem.

b. Aktor merupakan elemen yang melakukan aksi terhadap sistem, aktor dapat berupa orang ataupun sistem lain yang berinteraksi dengan use case.

c. Use case merupakan potongan proses yang menjadi bagian dari sistem.

d. Association menggambarkan hubungan antara use case dan aktor.

e. Dependency menggambarkan hubungan atau relasi antara dua use case.

f. Generalization menggambarkan pewarisan antara dua aktor atau use case yang salah satu aktor atau use case mewarisi bagiannya ke aktor atau use case yang lain.

Pada Use Case Diagram terdapat relasi, relasi tersebut digambarkan sebagai sebuah garis antara dua simbol. Relasi memiliki makna yang berbeda-beda tergantung garis dari relasi tersebut dan tipe symbol apa yang digunakan untuk menghubungkan garis tersebut [19].

Sedangkan menurut Tohari, use case adalah rangkaian atau uraian sekelompok yang saling terkait dan membentuk sistem secara teratur yang dilakukan atau diawasi oleh sebuah actor. Use casedigunakan untuk membentuk tingkah laku benda dalam sebuah model serta direalisasikan oleh sebuah kolaborasi [20].
(P) ISSN 2442-451X

(O) ISSN 2503-3832

\section{METODE YANG DIUSULKAN}

\subsection{Studi Pustaka}

Studi pustaka adalah metode yang digunakan untuk mengumpulkan data yang berkaitan dengan topik permasalahan yang bersifat teoritis dengan cara membaca makalah, jurnal penelitian dan membaca bahan-bahan sumber referensi lainnya. Studi pustaka bertujuan untuk memeberikan landasan berpikir yang logis bagi penelitian dan agar memperoleh acuan dalam melaksanakan penelitian yang dapat dijadikan sebagai pembanding terhadap hasil penelitian yang dilakukan.

\subsection{Pengumpulan Data}

Pengumpulan data dilakukan dengan mengumpulkan data yang berhubungan dengan topik yang akan diteliti. Metode pengumpulan data terdiri dari beberapa tahap yaitu:

a. Metode Observasi

Merupakan metode pengumpulan data dengan cara melakukan pengamatan terhadap objek penelitian secara langsung dan kemudian menarik kesimpulan dari seluruh kegiatan pada objek tersebut. Observasi dilakukan di SMK Negeri 2 Karawang.

b. Metode Wawancara

Merupakan metode pengumpulan data melalui tatap muka secara langsung dengan pihak-pihak tertentu, dalam hal ini adalah kepada pimpinan dan staff BKK SMK Negeri 2 Karawang.

\subsection{Rekayasa Kebutuhan Fungsional}

Tahapan dalam rekayasa kebutuhan fungsional sebagai berikut [15]:

a. Identifikasi masalah dilakukan untuk mengetahui masalah-masalah yang ada, dengan menggunakan kerangka PIECES yang didapat dari tahap pengumpulan data. Analisis pieces juga digunakan sebagai langkah awal untuk memulai melakukan analisis fishbone.

b. Analisis Sebab Akibat, pada tahapan ini menggunakan metode analisis fishbone untuk mengidentifikasi, mengeksplorasi, dan secara grafik menggambarkan secara detail semua penyebab yang berhubungan dengan suatu permasalahan yang di temukan dari analisis pieces yang sebelumnya digunakan.

c. Analisis Solusi Masalah, setelah melakukan tahapan analisis sebab akibat dengan diagram fishbone, menemukan akar masalah berdasarkan hasil dari analisis fishbone dan menganalisis solusi yang tepat untuk mengatasi akar dari masalah. Dan menjadi landasan untuk menganalisis kebutuhan-kebutuhan fungsional yang diperlukan dalam merancang dan membangun sistem.

d. Analisis kebutuhan fungsional merupakan tahapan untuk menetukan kebutuhan-kebutuhan fungsional yang dibutuhkan oleh sistem. 
Jurnal Ilmiah Ilmu Komputer Vol. 6, No. 2, September 2020 Fakultas Ilmu Komputer

Universitas AL Asyariah Mandar

e. Pemodelan fungsi analisa kebutuhan. Dalam tahap terakhir ini dilakukan pemodelan hasil analisa kebutuhan dengan menggunakan diagram use case.

\section{HASIL PENELITIAN}

\subsection{Identifikasi Masalah}

Hasil dari observasi dan wawancara dengan Kepala BKK dapat diidentifikasi beberapa masalah berdasarkan kerangka analisis PIECES. Tabel 1 merupakan hasil identifikasi masalah menggunakan analisis PIECES.

Tabel 1 Matriks Analisis PIECES

\begin{tabular}{|l|l|}
\hline \multicolumn{1}{|c|}{ Kategori } & \multicolumn{1}{|c|}{ Identifikasi Masalah } \\
\hline Performance & $\begin{array}{l}\text { Waktu yang dibutuhkan untuk mencari } \\
\text { data pelamar membutuhkan waktu } \\
\text { yang lama. }\end{array}$ \\
\hline Information & $\begin{array}{l}\text { Informasi yang dihasilkan dari } \\
\text { penyimpanan data pelamar terkadang } \\
\text { kurang rinci bahkan ada data pelamar } \\
\text { yang hilang. }\end{array}$ \\
\hline Economy & $\begin{array}{l}\text { Pengarsipan menggunakan kertas } \\
\text { membutuhkan biaya yang lumayan } \\
\text { besar. }\end{array}$ \\
\hline Eficiency & $\begin{array}{l}\text { Pata yang disimpan kurang aman. } \\
\text { dan waktu yang lama. }\end{array}$ \\
\hline Services & $\begin{array}{l}\text { Pelayanan saat akan memberikan data } \\
\text { dan mencatat data memerlukan waktu } \\
\text { yang lama sehingga membuat antrian } \\
\text { pendaftaran menjadi lama. }\end{array}$ \\
\hline
\end{tabular}

\subsection{Analisis Sebab Akibat}

Hasil dari analisis PIECES teridentifikasi masalahmasalah berdasarkan kategori performance, information, ekonomi, control, eficiency, dan service. Dari hasil tersebut dapat di identifikasi lagi faktor-faktor penyebabnya.

Adapun faktor-faktor penyebab dari masalah yang telah teridentifikasi dapat dilihat pada tabel 2 sebagai berikut:

Tabel 2 Faktor Penyebab Masalah

\begin{tabular}{|l|l|}
\hline \multicolumn{2}{|c|}{ Performance } \\
\hline Masalah & $\begin{array}{l}\text { Waktu yang dibutuhkan untuk mencari } \\
\text { data pelamar membutuhkan waktu yang } \\
\text { lama. }\end{array}$ \\
\hline Penyebab & $\begin{array}{l}\text { Data disimpan di tempat pencatatan data } \\
\text { yang berbeda serta data juga belum } \\
\text { diolah. }\end{array}$ \\
\hline Masalah & $\begin{array}{l}\text { Information } \\
\text { penyimpanan data pelamar terkadang } \\
\text { kurang rinci bahkan ada data pelamar } \\
\text { yang hilang. }\end{array}$ \\
\hline Penyebab & $\begin{array}{l}\text { Data hanya dicatat di buku data pelamar } \\
\text { yang pencatatannya terkadang kurang } \\
\text { rinci serta penyimpanannya yang kurang } \\
\text { aman. }\end{array}$ \\
\hline
\end{tabular}

\begin{tabular}{|c|c|}
\hline Masalah & $\begin{array}{llr}\text { Pengarsipan menggunakan } & \text { kertas } \\
\text { membutuhkan } & \text { biaya yang lumayan } \\
\text { besar. } & & \end{array}$ \\
\hline Penyebab & $\begin{array}{l}\text { Pencatatan data hanya mengandalkan } \\
\text { kertas dan dalam membuat informasi } \\
\text { lowongan serta form pendaftaran juga } \\
\text { masih mengandalkan banyak kertas } \\
\text { sehinga biaya yang dibutuhkan lumayan } \\
\text { besar. }\end{array}$ \\
\hline \multicolumn{2}{|r|}{ Control } \\
\hline Masalah & Data yang disimpan kurang aman. \\
\hline Penyebab & $\begin{array}{l}\text { Pencatatan data pelamar dilakukan oleh } \\
\text { Staff BKK dan dalam penggunaannya } \\
\text { tidak ada batasan untuk siapapun bisa } \\
\text { melihat data pelamar. }\end{array}$ \\
\hline \multicolumn{2}{|r|}{ Eficiency } \\
\hline Masalah & $\begin{array}{l}\text { Pengelohan data memerlukan tenaga dan } \\
\text { waktu yang lama. }\end{array}$ \\
\hline Penyebab & $\begin{array}{l}\text { Data yang hanya disimpan secara } \\
\text { manual sehingga saat membutuhkan data } \\
\text { tersebut harus mencari data satu persatu } \\
\text { di buku data pelamar. }\end{array}$ \\
\hline \multicolumn{2}{|r|}{ Services } \\
\hline Masalah & $\begin{array}{l}\text { Pelayanan saat akan memberikan data } \\
\text { dan mencatat data memerlukan waktu } \\
\text { yang lama sehingga membuat antrian } \\
\text { pendaftaran menjadi lama. }\end{array}$ \\
\hline Penyebab & $\begin{array}{l}\text { Penyimpanan yang masih manual } \\
\text { membuat sulit saat data dibutuhkan } \\
\text { karena harus mencari data satu persatu. }\end{array}$ \\
\hline
\end{tabular}

Hasil dari kegiatan identifikasi masalah dan penyebabnya dapat digambarkan dalam diagram fishbone dalam menjelaskan keterkaitan antara masalah dan penyebabnya yang mengakibatkan pihak manajemen kesulitan dalam pembuatan laporan.

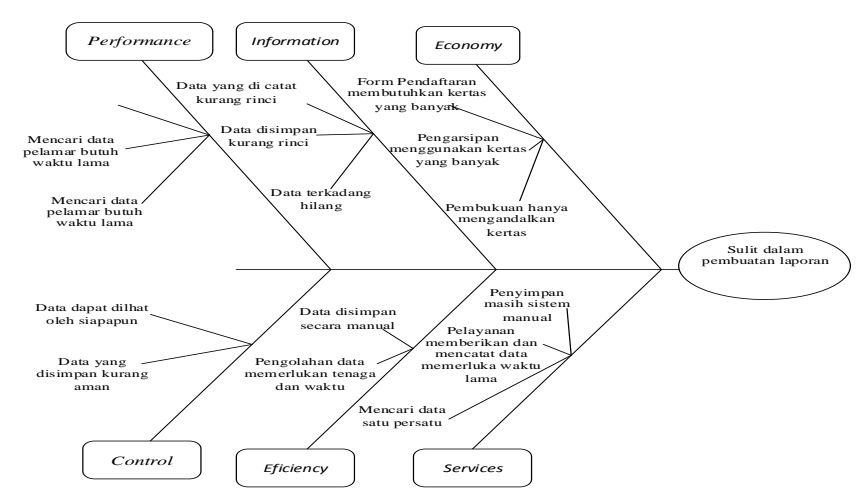

Gambar 3 Diagram Fishbone

\subsection{Analisis Solusi}

Pada tahapan menganalisis solusi masalah yang akan dilakukan terlebih dahulu adalah mengidentifikasi akar masalah, dari hasil analisa sebab akibat dan membagi akar masalah tersebut berdasarkan input, proses dan output sehingga memudahkan dalam memberikan solusi masalah. 
Jurnal Ilmiah Ilmu Komputer Vol. 6, No. 2, September 2020

Fakultas Ilmu Komputer

Universitas AL Asyariah Mandar

Berikut ini pada tabel 3 diuraian dari analisis solusi masalah yang didasarkan kategori input, proses dan output hasil dari identifikasi akar masalah.

Tabel 3 Identifikasi Solusi Masalah

\begin{tabular}{|c|c|}
\hline \multicolumn{2}{|r|}{ Input } \\
\hline Akar Masalah & $\begin{array}{l}\text { Penggunaan sistem yang manual } \\
\text { dengan mencatat data pelamar dari } \\
\text { form pendaftaran oleh staff BKK } \\
\text { kedalam buku data pelamar sering } \\
\text { membuat sulit saat harus mencari data } \\
\text { pelamar karena harus mencari data satu } \\
\text { persatu serta membutuhkan waktu } \\
\text { yang lama. }\end{array}$ \\
\hline Solusi & $\begin{array}{l}\text { Membuat sistem pendaftaran online } \\
\text { yang terintegrasi sehingga } \\
\text { administrator tidak perlu lagi mencatat } \\
\text { data secara ulang dan saat } \\
\text { membutuhkan data pelamar lebih } \\
\text { mudah dalam mencari. }\end{array}$ \\
\hline \multicolumn{2}{|r|}{ Process } \\
\hline Akar Masalah & $\begin{array}{l}\text { Sistem pengolahan data yang masih } \\
\text { manual menyulitkan dalam } \\
\text { penyampaian informasi. Dan juga } \\
\text { pengarsipan data yang secara terpisah } \\
\text { menyulitkan dalam mendapatkan } \\
\text { informasi. }\end{array}$ \\
\hline Solusi & $\begin{array}{l}\text { Membuat sistem informasi yang } \\
\text { terkomputersasi yang mempermudah } \\
\text { dalam pengolahan informasi berupa } \\
\text { data lowongan kerja , identitas } \\
\text { pelamar, identitas perusahaan, posisi } \\
\text { yang diingkan, keahlian khusus yang } \\
\text { dimiliki, dan jadwal tes yang saling } \\
\text { terintegrasi sehingga mempermudah } \\
\text { dan mempercepat dalam pencarian } \\
\text { data. Data yang didapat juga akurat. }\end{array}$ \\
\hline \multicolumn{2}{|r|}{ Output } \\
\hline Akar Masalah & $\begin{array}{l}\text { Dalam pencatatan dan pemberian } \\
\text { informasi menganai data pelamar } \\
\text { membutuhkan waktu yang lama karena } \\
\text { sistem masih manual. }\end{array}$ \\
\hline Solusi & $\begin{array}{l}\text { Membuat sistem yang mampu } \\
\text { menyajikan informasi secara cepat dan } \\
\text { akurat serta dalam membantu dalam } \\
\text { membuat laporan seperti banyak } \\
\text { pelamar yang pelamar, banyak } \\
\text { perusahaan yang membutuhkan } \\
\text { karyawan baru, posisi yang paling } \\
\text { banyak diinginkan dan dicari. }\end{array}$ \\
\hline
\end{tabular}

\subsection{Analisa Kebutuhan Fungsional}

Analisa kebutuhan fungsional merupakan tahap menentukan kebutuhan sistem yang akan dibuat. Dalam hal ini akan dijabarkan kemampuan perangkat lunak yang akan dikembangkan berdasarkan analisis solusi masalah.

Dalam BKK SMK Negeri 2 Karawang dapat dipetakan kebutuhan fungsi dan perangkat lunak berdasarkan pengguna sistem diantaranya Kepala BKK, perusahaan, staff BKK, dapat dilihat pada tabel 4, 5, 6 dan 7, berikut:

Tabel 4 Analisa Kebutuhan Kepala BKK

\begin{tabular}{|c|lr|l|}
\hline No. & \multicolumn{2}{|c|}{ Kebutuhan Utama } & \multicolumn{1}{|c|}{ Tujuan } \\
\hline 1. & $\begin{array}{l}\text { Menampilkan data } \\
\text { pelamar yang akan } \\
\text { mengikuti tes kerja } \\
\text { ataupun yang sudah } \\
\text { mengikuti tes kerja. }\end{array}$ & $\begin{array}{l}\text { Untuk mengetahui } \\
\text { banyaknya peserta yang } \\
\text { terdaftar di BKK. }\end{array}$ \\
\hline 2. & $\begin{array}{l}\text { Menampilkan } \\
\text { informasi pendaftaran } \\
\text { tes. }\end{array}$ & $\begin{array}{l}\text { Untuk mengetahui } \\
\text { jumlah pelamar yang } \\
\text { terdaftar dan pendapatan } \\
\text { BKK. }\end{array}$ \\
\hline 3. & $\begin{array}{l}\text { Menampilkan data } \\
\text { perusahaan yang } \\
\text { bekerjasama dengan } \\
\text { BKK. }\end{array}$ & $\begin{array}{l}\text { Untuk mengetahui } \\
\text { berapa } \\
\text { perusahaan yang bekerja } \\
\text { sama. }\end{array}$ \\
\hline 4. & $\begin{array}{l}\text { Menampilkan data } \\
\text { mengenai lowongan } \\
\text { kerja. }\end{array}$ & $\begin{array}{l}\text { Untuk mengetahui } \\
\text { banyaknya perusahaan } \\
\text { yang sedang membuka } \\
\text { lowongan kerja. }\end{array}$ \\
\hline
\end{tabular}

Tabel 5 Analisa Kebutuhan Perusahaan

\begin{tabular}{|c|l|l|}
\hline No. & Kebutuhan Utama & \multicolumn{1}{|c|}{ Tujuan } \\
\hline 1. & $\begin{array}{l}\text { Memberitahukan } \\
\text { informasi lowongan } \\
\text { kerja. }\end{array}$ & $\begin{array}{l}\text { Untuk mempermudah } \\
\text { dalam menyampaikan } \\
\text { informasi kepada kepala } \\
\text { BKK. }\end{array}$ \\
\hline 2. & $\begin{array}{l}\text { Laporan data peserta } \\
\text { Tes Lowongan Kerja. }\end{array}$ & $\begin{array}{l}\text { Untuk mendapatkan } \\
\text { laporan lebih cepat. }\end{array}$ \\
\hline
\end{tabular}

Tabel 6 Analisa Kebutuhan Staff BKK

\begin{tabular}{|c|c|c|}
\hline No. & Kebutuhan Utama & Tujuan \\
\hline 1. & $\begin{array}{lr}\text { Mengelola } & \text { data } \\
\text { pelamar } & \text { yang } \\
\text { mendaftar. } & \end{array}$ & $\begin{array}{l}\text { Memastikan data yang } \\
\text { diisi oleh pelamar benar } \\
\text { dan sesuai dengan } \\
\text { kriteria lowongan kerja. }\end{array}$ \\
\hline 2. & $\begin{array}{l}\text { Melakukan } \\
\text { penjadwalan daftar } \\
\text { ulang dan tes kerja. }\end{array}$ & $\begin{array}{l}\text { Untuk mempermudah } \\
\text { dalam membuat jadwal } \\
\text { serta menginformasikan } \\
\text { kepada pelamar. }\end{array}$ \\
\hline 3. & $\begin{array}{l}\text { Melakukan } \\
\text { pemanggilan kepada } \\
\text { pelamar. }\end{array}$ & $\begin{array}{l}\text { Untuk mempermudah } \\
\text { dalam pemanggilan tes. }\end{array}$ \\
\hline 4. & \begin{tabular}{lr}
\multicolumn{2}{l}{ Menginformasikan } \\
mengenai lowongan \\
kerjarangan dengan \\
mempublikasikannya.
\end{tabular} & $\begin{array}{l}\text { Untuk } \\
\text { menginformasikan } \\
\text { mengenai lowongan } \\
\text { kerja kepada pelamar } \\
\text { dengan lebih mudah. }\end{array}$ \\
\hline 5 . & $\begin{array}{l}\text { Mencetak } \\
\text { pembayaran } \\
\text { pendaftaran. }\end{array}$ & $\begin{array}{lr}\text { Sebagai } & \text { bukti } \\
\text { pembayaran pendaftaran } \\
\text { dan mempermudah } \\
\text { membuat } \\
\text { keuangan. }\end{array}$ \\
\hline
\end{tabular}

Tabel 7 Analisa Kebutuhan Pelamar

\begin{tabular}{|l|l|l}
\hline No. & Kebutuhan Utama & Tujuan \\
\hline
\end{tabular} 
Jurnal Ilmiah Ilmu Komputer Vol. 6, No. 2, September 2020 Fakultas Ilmu Komputer

Universitas AL Asyariah Mandar

\begin{tabular}{|c|l|l|}
\hline 1. & $\begin{array}{l}\text { Mengetahui informasi } \\
\text { mengenai lowangan } \\
\text { kerja. }\end{array}$ & $\begin{array}{l}\text { Untuk mengetahui } \\
\text { informasi lowongan } \\
\text { kerja lebih mudah. }\end{array}$ \\
\hline 2. & $\begin{array}{l}\text { Melakukan } \\
\text { pendaftaran. }\end{array}$ & $\begin{array}{l}\text { Untuk melakukan } \\
\text { pendaftaran lebih mudah } \\
\text { dan cepat. }\end{array}$ \\
\hline 3. & $\begin{array}{l}\text { Mengetahui jadwal } \\
\text { pelaksanaan tes. }\end{array}$ & $\begin{array}{l}\text { Untuk mengetahui } \\
\text { jadwal tes lebih cepat } \\
\text { dan akurat. }\end{array}$ \\
\hline 4. & $\begin{array}{l}\text { Pembayaran } \\
\text { pendaftaran. }\end{array}$ & $\begin{array}{l}\text { Lebih mudah dalam } \\
\text { membayar pendaftaran } \\
\text { karena dapat melalui } \\
\text { transfer. }\end{array}$ \\
\hline
\end{tabular}

\subsection{Pemodelan Fungsi Analisa Kebutuhan}

Setelah melakukan tahapan analisis kebutuhan, selanjutnya memodelkan sistem berdasarkan kebutuhan fungsional kedalam diagram use case.

Berikut model diagram use case dari sistem aplikasi BKK SMK Negeri 2 Karawang yang akan dibangun.

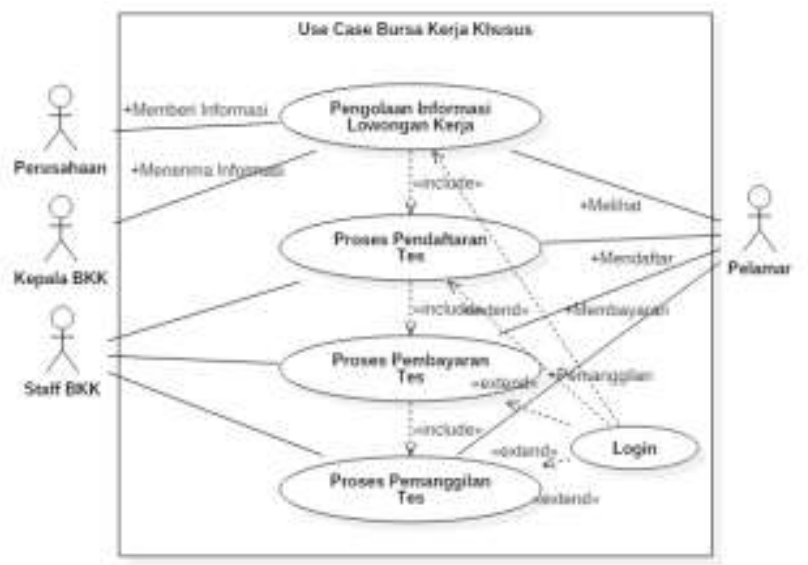

Gambar 4 Use Case Bursa Kerja Khusus

\section{KESIMPULAN}

Berdasarkan hasil penelitian yang telah dilakukan, maka diperoleh kesimpulan bahwa engan metode analisis pieces dapat ditentukan masalah-masalah berdasar kategori perfomance, information, economy, control, eficiency, and services. Hasil dari analisis pieces dapat digunakan dalam mengidentifikasi faktor-faktor penyebab masalah yang mengakibatkan staff BKK kesulitan dalam melakukan pembuatan laporan. Dimana penyebab dan akibata permasalahan dapat dipetakan dengan diagram fishbone berdasarkan kategori yang ada dianalisis pieces. Hasil identifikasi akar masalah dan solusi berdasarkan input, proses dan output dapat dijadikan rujukan dalam merekayasa kebutuhan fungsional yang diperlukan dalam membangun sistem informasi dalam aplikasi BKK. Dari analisis kebutuhan fungsional sistem informasi yang diperlukan oleh pihak BKK SMK Negeri 2 Karawang yaitu dapat melakukan mengelola data pelamar, data lowongan,
(P) ISSN 2442-451X

(O) ISSN 2503-3832

data perusahaan, jadwal tes dan pembayaran tes (menampilkan, menambahkan, menghapus dan mencetak) serta dapat mengelola laporan pelamar, pendaftaran serta laporan perusahaan.

\section{UCAPAN TERIMA KASIH}

Penulis menyadari sepenuhnya bahwa pada proses penulisan karya ilmiah ini dari awal sampai akhir tidak luput dari segala kekurangan dan kelemahan penulis sendiri maupun berbagai hambatan dan kendala yang sifatnya datang dari eksternal selalu mengiringiproses penulisan. Namun hal itu dapatlah teratasi lewat bantuan dari semua pihak yang dengan senang hati membantu penulis dalam proses penulisan ini. Oleh sebab itu penulis menyampaikan ucapan terimakasih kepada seluruh pihak yang telah turut membatu penulis dalam menyelesaikan karya ilmiah ini.

\section{Daftar Pustaka}

[1] "Bursa Kerja Khusus (BKK)," DIREKTORAT PEMBINAAN SMK DIREKTORAT JENDERAL PENDIDIKAN DASAR DAN MENENGAH KEMENTERIAN PENDIDIKAN DAN KEBUDAYAAN. [Daring]. Tersedia pada: https://bkk.ditpsmk.net/about. [Diakses: 20-Jul2020].

[2] H. Nibrastari dan E. Roesminingsih, "Peran Humas dalam Membangun Relationship di Sekolah Menengah Kejuruan Negeri 5 Surabaya," J. Manaj. Pendidik., vol. 01, no. 01, hal. 1-10, 2018.

[3] "Tujuan BKK (Bursa Kerja Khusus)." [Daring]. Tersedia pada: http://www.bkk.smkn2muaraenim.sch.id/tujuanbkk-bursa-kerja-khusus. [Diakses: 21-Jul-2020].

[4] Y. Heriyanto, "Perancangan Sistem Informasi Rental Mobil Berbasis Web Pada PT.APM Rent Car," J. Intra-Tech, vol. 2, no. 2, hal. 64-77, 2018.

[5] P. A. D. Pangastuti dan D. Priantinah, "Penerapan Sistem Informasi Raport Online," Ekuitas J. Pendidik. Ekon., vol. 7, no. 1, hal. 1-4, 2019, doi: 10.23887/ekuitas.v7i1.16488.

[6] S. Wahyudi, "PENGEMBANGAN SISTEM INFORMASI KLINIK BERBASIS WEB (Studi Kasus: Klinik Surya Medika Pasir Pengaraian)," Riau J. ofComputer Sci., vol. 06, no. 01, hal. 50-57, 2020.

[7] M. Ardiyansah dan R. M. Manikam, "Prototype EOrder pada Restoran Bebek Goreng Haji Yogi Menggunakan Metode PIECES," J. Ilm. Fifo, vol. XI, no. 2, hal. 189-197, 2019, doi: http://dx.doi.org/10.22441/fifo.2019.v11i2.008.

[8] I. D. Sintawati dan T. Hartati, "ANALISA METODE PIECES UNTUK SISTEM PENJUALAN ALAT PROTEKSI RADIASI PADA CV. KASHELARA JAKARTA," J. AKRAB JUARA, vol. 5, no. 2, hal. 262-271, 2020.

[9] A. Y. Lusfiani dan R. Priambodo, "Analisis dan Perancangan Aplikasi Jabatan Pimpinan Tinggi 
Pratama (SIJAPTI) Kantor Komisi Aparatur Sipil Negara," J. Sisfokom (Sistem Inf. dan Komputer), vol. 8, no. 2, hal. 199-206, 2019, doi: 10.32736/sisfokom.v8i2.626.

[10] F. Benny dan R. A. Kristianti, "PENGEMBANGAN SISTEM INFORMASI BERBASIS WEB UNTUK PT. XYZ," J. Manaj. BISNIS DAN KEWIRAUSAHAAN, vol. 02, no. 1, hal. 122-129, 2018, doi: 10.1017/CBO9781107415324.004.

[11] A. N. R. Azismustafa dan B. C. Putra, "Implementasi Penjualan Berbasis E-Commerce Studi Kasus: Toko Elisa Baru," J. IDEALIS, vol. 2, no. 2, hal. 92-98, 2019.

[12] B. Aprina, "ANALISA OVERALL RESOURCE EFFECTIVENESS UNTUK MENINGKATKAN DAYA SAING DAN OPERATIONAL EXCELLENCE," JITMI, vol. 2, no. 1, 2019.

[13] I. Surya, "Kebutuhan Perangkat Lunak Untuk Aplikasi Data Mining," J. Nas. Teknol. dan Sist. Inf., vol. 3, no. 2, hal. 233-240, 2017, doi: 10.25077/teknosi.v3i2.2017.233-240.

[14] N. M. Sadila, F. Pradana, dan B. Priyambadha, "Rekayasa Kebutuhan dengan Metode Pemodelan Berbasis Linguistik dan Ontologi pada Sistem Penilaian Prestasi Kerja Pegawai Dinas Kominfo Kota Malang," J. Pengemb. Teknol. Inf. dan Ilmu Komput., vol. 1, no. 9, hal. 765-773, 2017.

[15] A. Yasin, Y. MZ, dan T. Fitriyad, "Analisis Kebutuhan Sistem Informasi di LPK RJ-COMP Yogyakarta," Semin. Nas. Inform., hal. 111-116, 2015.

[16] R. S. Pressman, Rekayasa Perangkat Lunak, Buku 1. Penerbit: Andi Offset, 2012.

[17] R. F. Rasyid, F. Pradana, dan B. Priyambadha, "Pengembangan Sistem Peringatan Dini Masa Kontrak Kerja Karyawan dengan Menerapkan Pendekatan Kolaboratif Athena pada Elisitasi Kebutuhan (Studi Kasus PT. Surya Optima Nusa Raya)," J. Pengemb. Teknol. Inf. dan Ilmu Komput., vol. 1, no. 11, hal. 1178-1187, 2017.

[18] S. Mulyani, Analisis dan Perancangan Sistem Informasi Manajemen Keuangan Daerah: Notasi Pemodelan Unified Modeling Language (UML). Bandung: Abdi Sistematika, 2016.

[19] E. Tan dan R. V. Imbar, "Pembuatan Enterprise Architecture untuk Gereja Jemaat Kristus Indonesia Menggunakan TOGAF Framework," J. Strateg., vol. 1, no. 2, hal. 512-526, 2019.

[20] A. Karim, A. R. Mariana, dan A. Ahmadi, "Implementasi Sistem Informasi Cut Off Menggunakan FINA Pada Poly Jaya Pratama," J. Sisfotek Glob., vol. 9, no. 2, hal. 20-25, 2019. 